\title{
HUBUNGAN KEMAMPUAN KOMUNIKASI DAN PEMAHAMAN MATEMATIS SISWA KELAS X IPA SMA NEGERI 7 BALIKPAPAN TAHUN AJARAN 2017/2018
}

\author{
Ni’matur Rochmah ${ }^{1}$, Tri Hariyati Nur Indah Sari $^{2}$, Besse Intan Permatasari ${ }^{3}$ \\ Universitas Balikpapan ${ }^{1}$, Universitas Balikpapan ${ }^{2}$, Universitas Balikpapan ${ }^{3}$ \\ pos-el : nimaturrochmah18@gmail.com²,tri.hariyati.nis@uniba-bpn.ac.id, \\ besse.intan@uniba-bpn.ac.id ${ }^{3}$
}

\begin{abstract}
ABSTRAK
Penelitian ini bertujuan untuk mengetahui apakah terdapat hubungan yang positif dan signifikan antara kemampuan komunikasi dan pemahaman matematis siswa kelas X IPA SMA Negeri 7 Balikpapan Tahun Ajaran 2017/2018. Teknik pengambilan sampel menggunakan teknik simple random sampling. Metode pengumpulan data menggunakan wawancara tidak terstruktur untuk mencari data literatur awal kepada salah satu guru matematika, dan tes digunakan untuk mengukur pengetahuan siswa. Uji prasyarat analisis berupa uji normalitas dan linieritas. Teknik analisis yang digunakan adalah korelasi product moment. Teknik analisis data uji prasyarat menggunakan software SPSS windows 23. Hasil penelitian menunjukkan bahwa terdapat hubungan yang positif dan signifikan antara kemampuan komunikasi dan pemahaman matematis siswa. Hal ini dibuktikan dengan nilai $r$ sebesar 0,085 dan nilai signifikansi $0,388 \geq 0,05$.
\end{abstract}

Kata kunci : Komunikasi Matematis, Pemahaman Matematis

\begin{abstract}
The research aimed to determine whether there is a positive and significant Relationship between Communication Capability and Mathematical Understanding of Grade X Science Class Students SMA Negeri 7 Balikpapan Academic Year 2017/2018. The sampling technique used simple random sampling technique. Data collection method used unstructured interview to find the initial literature data to one of the mathematics teachers, a test used to measure students' knowledge. Analysis prerequisite test in the form of normality and linearity test. The analysis technique used is product moment correlation. Prerequisite test and analysis technique using SPSS windows 23. The results showed that there was a positive and significant relationship between communication skills and mathematical understanding of students. This is evidenced by the $r$ value of 0,085 and significance value of $0,388 \geq 0,05$.
\end{abstract}

Keywords: Mathematical Communication, Mathematical Understanding

\section{PENDAHULUAN}

Salah satu faktor yang menjadi siswa merasa kesulitan dalam mengerjakan soal matematika yaitu bentuk soal matematika yang sulit dipahami bahasanya, sehingga siswa sering kali membatasi kemampuannya. Padahal menurut The
National Council of Teacher of Mathematics (2000) aspek kemampuan matematis yang harus dikuasai oleh siswa, yaitu: kemampuan pemecahan masalah, penalaran, komunikasi, koneksi dan representasi (Misel \& Suwangsih, 2016, p. 27). Oleh karena itu guru 
sebaiknya melatih kemampuan matematis siswa. Berdasarkan NTCM, salah satu kemampuan yang menjadi standar matematika disekolah yaitu kemampuan komunikasi matematis.

\begin{tabular}{lcr}
\multicolumn{1}{c}{ Selanjutnya } & NCTM & (2000) juga \\
menjelaskan & bahwa & kemampuan \\
komunikasi & matematis & merupakan
\end{tabular}
kemampuan untuk mengorganisasikan pikiran matematika, mengkomunikasikan gagasan matematika secara logis dan jelas kepada orang lain, menganalisis, mengevaluasi pikiran matematika, strategi yang digunakan orang lain dan menggunakan bahasa matematika untuk menyatakan ide-ide secara tepat (Asnawati, 2013, p. 561). Dalam hal ini peranan komunikasi dalam matematika sangat besar. Karena saat para siswa mengkomunikasikan ide, gagasan ataupun konsep matematika, siswa belajar menyatakan ulang, beserta menyatukan pemikiran terhadap apa yang sudah diperoleh.

Dari uraian di atas kemampuan komunikasi matematis yang telah dipahami oleh siswa merupakan hal yang penting, karena komunikasi matematis merupakan refleksi dari pemahaman matematis seseorang. Artinya jika siswa paham dengan materi yang diperolehnya maka siswa tersebut mampu mengkomunikasikan pemahamannya. Oleh karena itu komunikasi merupakan bagian dari proses belajar siswa yang dapat mempercepat suatu pemahaman. Sehingga selain kemampuan komunikasi matematis, kemampuan pemahaman juga harus dikuasi oleh siswa.

Hiebert (Fatqurhohman, 2015, p. 128) menyatakan pemahaman adalah suatu proses yang terdiri dari kemampuan untuk menerangkan dan mengintrepetasikan sesuatu, mampu memberikan gambaran, contoh, penjelasan yang lebih luas, memadai serta mampu memberikan uraian dan penjelasan yang lebih kreatif dan menyatakan ulang. Dengan adanya pemahaman memudahkan terjadinya transfer ilmu.

Putra, dkk (2018, p. 19) menyatakan kemampuan pemahaman matematis berkaitan dengan kemampuan siswa dalam memahami suatu konsep. Siswa dapat mencapai tujuan pembelajarannya apabila siswa dapat memahami konsep dengan baik. Lebih lanjut menurut Ansari (Martunis, Ikhsan, \& Rizal, 2014, p. 76) mengemukakan kemampuan pemahaman matematis merupakan salah satu aspek yang dapat mempengaruhi kemampuan komunikasi matematis.

Adapun tujuan dari penelitian ini adalah untuk mengetahui apakah terdapat hubungan positif dan signifikan antara kemampuan komunikasi dan pemahaman matematis siswa kelas $\mathrm{X}$ IPA SMA Negeri 7 Balikpapan Tahun Ajaran 2017/2018.

Penelitian yang dilakukan oleh Amelia \& Trisnawati (2015, p. 18) menunjukkan bahwa terdapat hubungan yang signifikan antara kemampuan komunikasi lisan dan kemampuan pemahaman matematis terhadap hasil belajar matematika. Berbeda dengan penelitian yang dilakukan oleh peneliti, peneliti ingin mengetahui hubungan kemampuan komunikasi dan pemahaman matematis siswa. Adapun penelitian Nufus \& Ariawan (2017, p. 37) menyimpulkan bahwa terdapat hubungan positif yang signifikan antara kemampuan komunikasi dan penalaran matematis siswa secara keseluruhan dan secara level sekolah pada tingkat (tinggi, sedang dan rendah). Hal ini sejalan dengan penelitian Sela, Halini \& Yani (2017, p. 12) yang menyatakan bahwa semakin baik kemampuan penalaran induktif siswa, maka akan semakin baik pula kemampuan pemahaman konsep siswa. 
Berdasarkan hasil wawancara dengan salah satu guru matematika SMA Negeri 7 Balikpapan diketahui bahwa sebagian siswa masih bingung dalam memahami materi sehingga siswa belum mampu dalam menyelesaikan yang dinyatakan dari soal. Dalam menyelesaikan soal metamatika siswa masih merasa kesulitan untuk bertanya, mengungkapkan pendapat bahkan menyanggah suatu pertanyan. Siswa juga lebih banyak menghafal jawaban pada soal latihan yang sama dari pada siswa memahami penyelesaiannya. Siswa juga belum mampu mengkomunikasikan atau menjelaskan jawaban yang diperolehnya baik secara tulisan.

Maka hipotesis dalam penelitian ini yaitu terdapat hubungan positif dan signifikan antara kemampuan komunikasi dan pemahaman matematis siswa kelas $\mathrm{X}$ IPA SMA Negeri 7 Balikpapan Tahun Ajaran 2017/2018.

Pengertian komunikasi yang di kemukakan oleh Berlo (Oktavia, 2016, p. 239) komunikasi sebagai suasana yang penuh keberhasilan jika dan hanya jika penerima pesan memiliki makna terhadap pesan tersebut dimana makna yang diperoleh sama dengan apa yang dimaksudkan oleh sumber. Komunikasi matematis juga merupakan cara bagi siswa utuk mengkomunikasikan ide-ide pemecahan masalah, strategi maupun solusi matematika baik secara tertulis maupun lisan (Wijaya, Sujadi, \& Riyadi, 2016, p. 778). Sedangkan menurut The Intended Learning Outcomes (Ramellan, Musdi, \& Armiati, 2012, p. 78) kemampuan komunikasi matematis yaitu kemampuan untuk mengekspresikan ideide matematika secara koheren kepada teman, guru, dan lainnya melalui bahasa lisan tulisan.

Pengertian komunikasi lainnya juga diungkapkan oleh Khoiriyah, Sujadi, \& Subanti (2016, pp. 34-35) yang menyatakan bahwa kemampuan komunikasi matematis adalah kecakapan siswa dalam mengungkapkan ide-ide matematika dengan menggunakan simbol, notasi, bahasa atau kalimat matematika.

Berdasarkan pendapat tersebut maka dengan adanya komunikasi matematis guru dapat lebih memahami kemampuan siswa dalam menginterpretasikan dan mengekspresikan pemahamannya tentang konsep yang siswa pelajari oleh karena itu komunikasi sebagai proses penyampaian pesan dari pengirim pesan kepada penerima pesan melalui saluran tertentu untuk tujuan tertentu. Salah satu unsur dari matematika adalah ilmu logika yang mampu mengembangkan kemampuan berpikir siswa. Dengan demikian, matematika memiliki peran penting terhadap perkembangan kemampuan komunikasi matemasinya (Hodiyanto, 2017, p. 11).

Adapun keakuratan dalam matematis tertulis menurut Maarif \& Nurmila (2015, p. 31) yaitu, (1) untuk menyampaikan hal-hal yang relevan dengan masalah, dikatakan akurat jika subjek menuliskan hal-hal yang relevan dengan masalah yang benar, (2) syaratsyarat atau rumus yang digunakan dikatakan akurat jika subjek menulis syarat-syarat atau rumus yang digunakan benar menurut kaidah matematika, (3) melakukan perhitungan dikatakan akurat jika subjek menuliskan langkah-langkah perhitungan yang diperlukan dengan benar sesuai dengan rumus.

Adapun indikator komunikasi matematis menurut Sumarmo (Alamsyah, 2015, p. 32) sebagai berikut :

a) Menghubungkan benda nyata, gambar, dan diagram kedalam ide matematika

b) Menjelaskan ide, situasi, dan relasi matematika, secara lisan atau tulisan dengan benda nyata, gambar, grafik dan aljabar 
c) Menyatakan peristiwa sehari-hari dalam bahasa atau simbol matematika

d) Mendengar, berdiskusi, dan menulis tentang matematika

e) Membaca presentasi matematika tertulis dan menyusun pernyataan yang relevan

f) Membuat konjektur, menyusun argumen, merumuskan definisi dan generalisasi

g) Menjelaskan dan membuat pertanyaan matematika yang telah dipelajari

Pemahaman matematis juga merupakan salah satu tujuan dari setiap materi yang disampaikan oleh guru, sebab guru merupakan pembimbing siswa untuk mencapai konsep yang diharapakan. Hal ini memberikan pengertian bahwa materimateri yang diajarkan kepada siswa bukan hanya sebagai hafalan sebagaimana yang diungkapkan oleh Marpaung (Sari, Nurochmah, Haryadi, \& Syaiturjim, 2016, p. 17) bahwa matematika tidak ada artinya bila hanya dihafalkan, namun dengan pemahaman siswa dapat lebih mengerti akan konsep materi pelajaran itu sendiri.

Dalam hal ini pemahaman mempengaruhi keyakinan siswa artinya siswa yang memahami matematika dengan baik akan mempunyai keyakinan yang positif, selanjutnya akan membantu perkembangan pengetahuan matematikanya. Dari penjelasan tersebut sudah jelas bahwa pemahaman merupakan dasar siswa untuk naik pada tahapan belajar matematika. Siswa akan dianggap paham apabila siswa telah mampu menyelesaikan soal secara mandiri.

NTCM (Syahbana, 2013, p. 5) mengungkapkan indikator kemampuan pemahaman matematis yakni :

a) Kemampuan menyatakan ulang konsep yang dipelajari b) Kemampuan mengklarifikasikan objek-objek berdasarkan dipenuhi atau tidaknya persyaratan yang membentuk konsep tersebut

c) Kemampuan menerapkan konsep secara algoritma pada pemecahan masalah

d) Kemampuan memberikan contoh dan bukan contoh dari konsep yang telah dipelajari

e) Kemampuan menyajikan konsep dalam berbagai macam bentuk representatif matematika

f) Kemampuan mengaitkan berbagai konsep matematika, dan

g) Kemampuan mengembangkan syarat perlu dan syarat cukup dari suatu konsep

\section{METODE PENELITIAN}

Pendekatan ini menggunakan penelitian kuantitatif yang artinya kualitas skor yang dituangkan kedalam angka kuantitatif dalam teknik pengumpulan dan analisis datanya. Data penelitiannya berupa angka-angka dan analisis data menggunakan statistik (Sugiyono, 2015, p. 13). Dengan desain penelitian korelasional.. Peneliti bertujuan mencari hubungan antara kemampuan komunikasi dan pemahaman matematis siswa tanpa terlebih dahulu memberikan perlakukan apapun.

Penelitian ini dilaksanakan pada bulan januari hingga agustus 2018. Populasi dalam penelitian ini adalah seluruh siswa kelas X IPA SMA Negeri 7 Balikpapa tahun 2017/2018 yang berjumlah 144 siswa, teknik pengambilan sampel menggunakan simple random sampling sehingga sampel yang representative dalam penelitian ini 105 siswa.

Instrumen penelitian yang digunakan adalah berupa instrumen tes komunikasi dan tes pemahaman komunikasi. Adapun data yang diguanakan diperoleh melalui 
kegiatan tes, yaitu dengan melakukan tes yang terdiri atas Sembilan soal (empat soal komunikasi matematis dan lima soal pemahaman matematis), dengan rincian indikator yang digunakan pada penelitian ini untuk kedua kemampuan sebagai berikut :

1. Kemampuan komunikasi matematis adalah kemampuan siswa dalam menyatakan gambar kedalam simbol atau model matematis, menyatakan situasi ke dalam simbol matematis, membaca dengan pemahaman suatu representasi matematis tertulis, mengungkapkan kembali uraian atau paragraf matematika dalam bahasa sendiri.

2. Kemampuan pemahaman matematis adalah kemampuan siswa untuk menyatakan ulang sebuah konsep, menerapkan konsep algoritma, kemampuan memberikan contoh dan bukan contoh dari konsep yang dipelajari, menyajikan konsep dalam berbagai macam bentuk representasi matematis, serta kemampuan mengaitkan konsep matematis yang dinyatakan secara tertulis.

Penelitian ini merupakan penelitian korelasional. Pengolahan data dilakukan menggunakan software SPSS 21. Sebelum instrumen digunakan dilakukan uji coba terlebih dahulu ke sekolah yang setara yaitu SMA Negeri 4 Balikpapan. Setelah instrumen di lakukan uji coba dan instrumen telah memenuhi kriteria peneliti. Instrumen tersebut digunakan untuk mengukur kemampuan komunikasi dan pemahaman siswa.

Sebelum mengadakan pengujian hipotesis terlebih dahulu dilakukan pengujian persyaratan analisis uji normalitas dengan metode liliefors. uji normalitas yang mengharuskan data berdistribusi normal, adapun rumus yag digunakan sebagai berikut :

$$
z_{i}=\frac{X_{i-} \bar{X}}{S}
$$

Sedangkan untuk uji linieritas bertujuan untuk mengetahui apakah variabel kemampuan komunikasi dan pemahaman matematis mempunyai hubungan yang linier.

Pengolahan data selanjutnya adalah uji korelasi dengan menggunakan korelasi pearson / product moment :

$$
r_{x y}=\frac{n(\Sigma X Y)-(\Sigma X)(\Sigma Y)}{\sqrt{\left\{n ( \Sigma X ^ { 2 } - ( \Sigma X ) ^ { 2 } \} \left\{n\left\{\left(\Sigma Y^{2}\right)-(\Sigma Y)^{2}\right\}\right.\right.}}
$$

Adapun pedoman untuk memberikan interpretasi terhadap koefisien korelasi yang diperoleh dari hasil perhitungan dapat dilihat pada Tabel 1 berikut.

Tabel 1

Pedoman Interpretasi Koefisien Korelasi

\begin{tabular}{|l|l|}
\hline $\begin{array}{c}\text { Interval } \\
\text { Koefisien }\end{array}$ & \multicolumn{1}{|c|}{ Kekuatan Hubungan } \\
\hline $0,00-0,199$ & Sangat rendah \\
\hline $0,20-0,399$ & Rendah \\
\hline $0,40-0,599$ & Sedang \\
\hline $0,60-0,799$ & Kuat \\
\hline $0,80-1,00$ & Sangat kuat \\
\hline
\end{tabular}

(Hadi, 2015, p. 251)

\section{HASIL DAN PEMBAHASAN}

Rangkuman hasil penelitian sebagai berikut :

Tabel 2

Hasil Penelitian

\begin{tabular}{|l|c|c|}
\hline & $\begin{array}{c}\text { Komunikasi } \\
\text { Matematis }\end{array}$ & $\begin{array}{c}\text { Pemahaman } \\
\text { Matematis }\end{array}$ \\
\hline$N$ Valid & 105 & 105 \\
\hline$N$ Missing & 0 & 0 \\
\hline Mean & 69.7429 & 69.7905 \\
\hline Std. Deviation & 11.36038 & 8.00684 \\
\hline Minimum & 38.00 & 53.00 \\
\hline Maximum & 98.00 & 87.00 \\
\hline
\end{tabular}

Berdasarkan Tabel 2 data hasil tes kemampuan komunikasi matematis yang terdiri dari 105 siswa, tanpa ada data yang dihilangkan (missing), pada tabel 
diperoleh mean atau rata-rata $=69.74$, standar deviation yaitu ukuran penyebaran data dari rata-ratanyadengan nilai sebesar $=11.36$, nilai minimum komunikasi matematis $=38.00$, dan nilai maximum pada komunikasi matematis $=$ 98.00.

Berdasarkan hasil analisa dan uji persyaratan analisis yang ada, sebaran dari masing-masing variabel normal dan memiliki keterikan linier yang baik, maka dapat dilanjutkan dengan pengujian hipotesis menggunakan statistik parametrik. Pengujian hipotesis dilakukan guna mengetahui apakah hipotesis yang diajukan dalam penelitian ini dapat diterima atau ditolak. Pengujian hipotesis dalam penelitian ini menggunakan uji korelas pearson, sehingga diperoleh :

Setelah menentukan hipotesis dan dilihat dari perhitungan pada nilai uji korelasi diperoleh nilai sig 0,388 yang artinya lebih besar dari 0,05 dan $H_{0}$ ditolak. Dapat disimpulkan bahwa terdapat hubungan yang linier positif dan signifikan antara kemampuan komunikasi dan pemahaman matematis siswa. Namun hasil koefisien korelasi kemampuan komunikasi dan pemahaman matematis siswa sebesar 0,085 yang berarti sangat rendah.

Tabel 3

Hasil Uji Korelasi Pearson

\begin{tabular}{|c|c|c|c|}
\hline \multicolumn{2}{|c|}{} & $\begin{array}{c}\text { Komunik } \\
\text { asi } \\
\text { matematis }\end{array}$ & $\begin{array}{c}\text { Pemaham } \\
\text { an } \\
\text { matematis }\end{array}$ \\
\hline \multirow{3}{*}{$\begin{array}{c}\text { Komunikasi } \\
\text { matematis }\end{array}$} & $\begin{array}{c}\text { Pearson } \\
\text { correlation }\end{array}$ & 1 & 0.085 \\
\cline { 2 - 4 } & $\begin{array}{c}\text { Sig. } \\
(2 \text {-tailed })\end{array}$ & & 0.388 \\
\cline { 2 - 4 } & $N$ & 105 & 105 \\
\hline \multirow{3}{*}{$\begin{array}{c}\text { Pemahaman } \\
\text { matematis }\end{array}$} & $\begin{array}{c}\text { Pearson } \\
\text { correlation }\end{array}$ & 0.085 & 1 \\
\cline { 2 - 4 } & $\begin{array}{c}\text { Sig. } \\
\text { (2-tailed) }\end{array}$ & 0.388 & \\
\cline { 2 - 4 } & $N$ & 105 & 105 \\
\hline
\end{tabular}

Berdasarkan analisis data diperoleh korelasi positif yang menunjukkan hubungan antara kemampuan komunikasi dan pemahaman matematis. Hasil analisis juga menunjukkan korelasi antara kedua variabel yang signifikan. Selanjutnya dapat diketahui keterkaitan antara indikator kemampuan komunikasi dan pemahaman matematis antara lain : seperti indikator nomor 1 tes pemahaman menjelaskan "kemampuan siswa dalam menyatakan ulang konsep yang dipelajari" maksudnya setelah siswa menerima materi yang disampaikan oleh guru sebelumnya, siswa diberikan soal apakah siswa dapat menuliskan ulang konsep tersebut dan apakah siswa dapat menghubungkan soal kedalam bahasa matematika, gambar maupun simbol matematika. Hal ini akan menjawab kemampuan komunikasi matematis pada indikator soal nomor 1 yaitu "menghubungkan benda nyata, gambar dan diagram kedalam ide matematika".

Selanjutnya indikator soal komunikasi nomor 4 "menjelaskan dan membuat pertanyaan matematika yang telah dipelajari" setelah siswa mampu menyelesaikan soal pada indikator tersebut siswa diharapkan dapat "memberikan contoh dan bukan contoh dari konsep yang telah dipelajari" maksudnya siswa mampu membedakan contoh dan bukan contoh dari suatu materi tersebut sesuai dengan indikator soal nomor 3 pemahaman matematis.

Adapun penelitian Ariani (2017, p. 100) yang mengatakan bahwa indikator kemampuan komunikasi dan pemahaman matematis memiliki keterkaitan yaitu : membantu siswa dalam merangsang cara berfikir kritis siswa dan meningkatkan kemampuan siswa dalam melihat berbagai keterkaitan materi matematika; alat pengukur perkembangan dan merefleksikan pemahaman matematika siswa; siswa dapat mengorganisasikan 
pemikiran matematika; komunikasi antar siswa dalam pembelajaran matematika berperan dalam mengkontruksikan pengetahuan matematika.

Dari uraian antara keterkaitan indikator tersebut, benar adanya bahwa penelitian ini telah menjawab hipotesis yang diajukan. Hasil penelitian ini menunjukkan terjadinya hubungan yang signifikan antara kemampuan komunikasi dan pemahaman matematis siswa. Hal ini sejalan dengan penelitian Amelia \& Trisnawati (2015, p. 18) yang mengatakan bahwa terdapat hubungan yang signifikan antara kemampuan komunikasi lisan dan kemampuan pemahaman matematis terhadap hasil belajar metamatika.

Namun hubungan yang terjadi pada penelitian ini sangat rendah yaitu $r_{x y}=$ 0,085 . Berikut jawaban siswa dalam menjawab tes nomor 1 pada soal komunikasi matematis "Amir berjalan ke arah barat mengunjungi rumah Cici dengan jarak $9 \mathrm{~m}$ setelah Amir pulang ke rumah, kemudian Cici berkunjung ke rumah Budi ke arah selatan dengan jarak $12 \mathrm{~m}$. Pada saat berjalan, Cici membentuk bayangan sudut dirumah Budi yaitu $\theta$, namun sudut tersebut belum diketahui. Tentukan nilai $\cos \theta$ !"

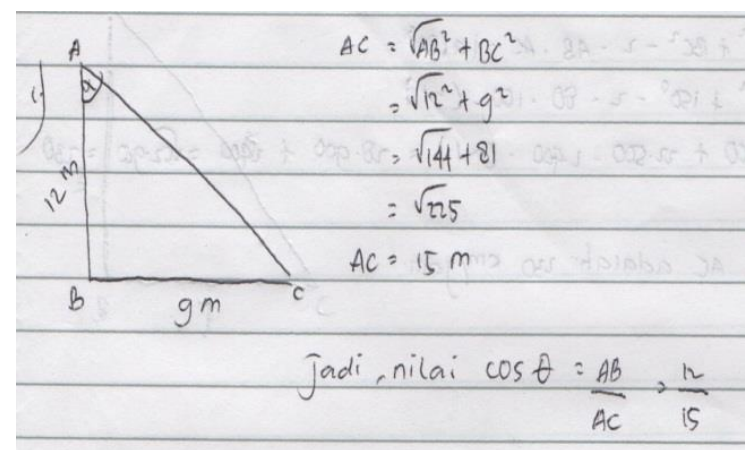

Gambar 1

Soal 1 Komunikasi Matematis

Berdasarkan Gambar 1 pada soal komunikasi matematis nomor 1 siswa kurang paham dengan petunjuk arah mata angin pada soal, sehingga gambar yang telah dibuat siswa salah. Siswa melakukan kesalahan dalam meletakkan sudut pada gambar. Siswa tidak melakukan prosedur menjawab soal dengan cara diketahui dan ditanya, namun rumus Pythagoras yang digunakan dalam menjawab soal benar. Hal ini dapat disimpulkan bahwa siswa tersebut tidak dapat menuliskan ulang pemahamannya.

Selanjutnya soal nomor 1 pemahaman matematis "di daerah pedesaan yang jauh dari bandar udara, kebiasaan anak-anak jika melihat atau mendengar pesawat udara sedang melintasi perkampungan, mereka mengikuti arah pesawat tersebut. Bolang mengamati sebuah pesawat udara yang terbang dengan ketinggian $12 \mathrm{~km}$. Dengan sudut elevasi pengamat (Bolang) terhadap pesawat sebesar $\theta=30^{\circ}$. Tentukan jarak pengamat ke pesawat!". Berdasarkan Gambar 2 siswa mampu menyatakan ulang konsep yang dipelajari sehingga mampu menyelesiakn soal dengan benar.

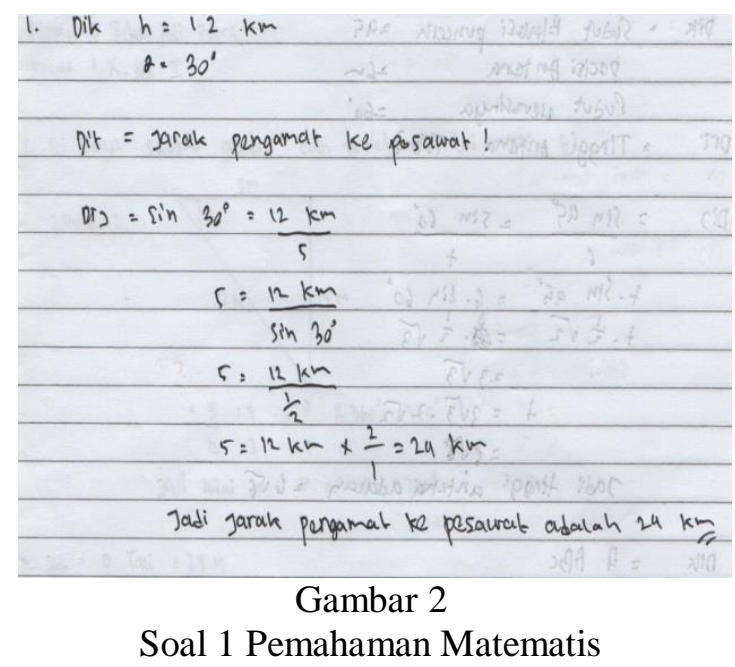

Pada soal nomor 3 tes komunikasi matematis yaitu "Diketahui sebuah segitiga siku-siku dengan sudut $\alpha$ dan sin $\alpha=\frac{1}{2}$. Siswa dapat menghitung nilai $\tan \alpha$ !". Berikut cuplikan jawaban siswa 


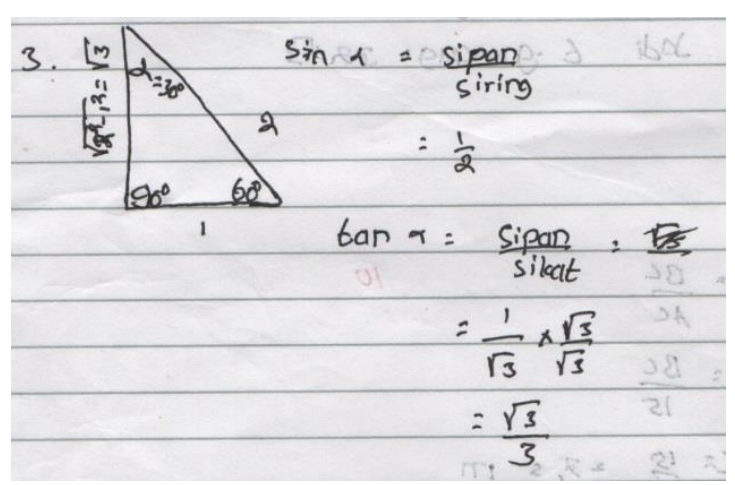

Gambar 3

Soal nomor 3 Komunikasi Matematis

Pada Gambar 3 soal komunikasi matematis siswa mampu menjawab soal dengan jawaban benar, namun jawaban tersebut tidak sesuai dengan prosedur. Yang mana siswa tidak menuliskan apa saja yang diketahui dan ditanya pada soal. Siswa tidak menuliskan rumus Pythagoras sesuai dengan langkah perlangkah. Sehingga akan mempengaruhi skor yag diperoleh. Padahal sebelum tes peneliti sudah menginstruksikan kepada siswa cara mengerjakannya harus sesuai dengan prosedur, dan didalam lembar soal juga sudah diberikan catatan.

Soal di atas berkaitan dengan soal nomor 4 \& 5 pemahaman matematis, akan di bahas satu persatu. Yang pertama soal nomor 4 "pada posisi tertetu, sudut elevasi puncak antena adalah $45^{\circ}$, pada posisi 6 meter yang lebih dekat ke antena tersebut, sudut elevasinya adalah $60^{\circ}$. Tentukanlah tinggi antena tersebut!".

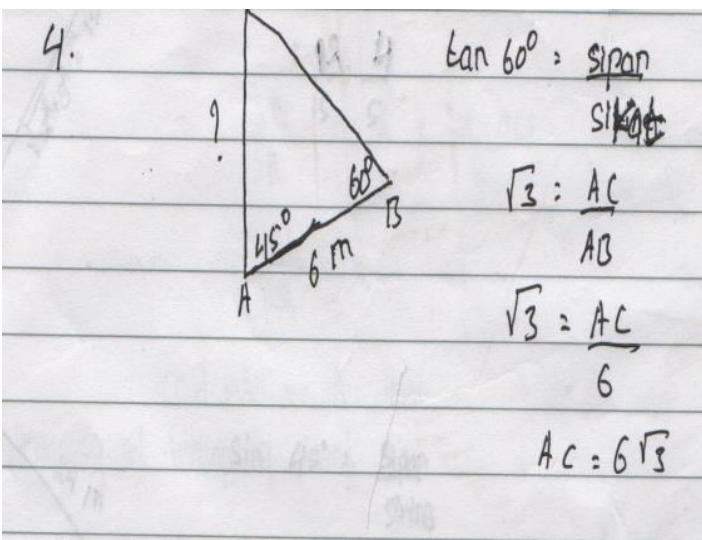

Gambar 4

Soal nomor 4 Pemahaman Matematis

Berdasarkan Gambar 4 adapun kesalahan - kesalahan yang dilakukan siswa yaitu siswa tidak dapat menyatakan soal cerita kedalam bentuk gambar. Siswa tidak menuliskan diketahui dan ditanya, dan siswa salah dalam menyelesaikan jawaban.

Selanjutnya pada soal nomor 5 pemahaman matematis "sebuah segitiga yang mana titik sudutnya diberi nama $\mathrm{ABC}$, dengan panjang sisi $\mathrm{AB}=3 \mathrm{~cm}$, $\mathrm{BC}=5 \mathrm{~cm}$ dan $\mathrm{AC}=7 \mathrm{~cm}$. Berapakah nilai $\cos$ A pada sudut atap rumah tersebut!".

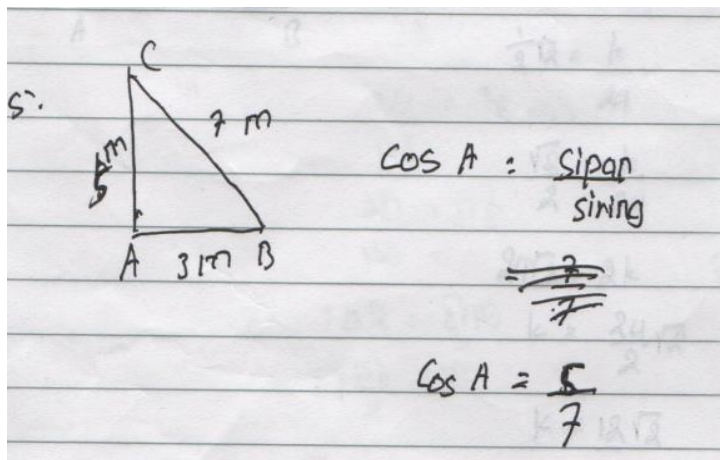

Gambar 5

Soal nomor 5 Pemahaman Matematis

Berdasarkan Gambar 5 adapun kesalahan yang dilakukan oleh siswa. Siswa tidak menuliskan diketahui, ditanya dan siswa terkecoh pada soal yang dimaksud, didalam soal yang ditanyakan 
nilai cos dengan penyelesaian menggunakan aturan cosinus, namun siswa menjawab dengan aturan mencari nilai cos biasa. Sehingga jawaban siswa mendapatkan skor rendah.

Berdasarkan uraian jawaban siswa dapat disimpulkan bahwa kemampuan komunikasi memiliki hubungan dengan pemahaman matematis, namun hubungan yang terjadi rendah. Hal ini dibuktikan pada hasil pengerjaan siswa, siswa yang dapat menjawab soal komunikasi matematis belum tentu dapat menjawab soal pemahaman, dan sebaliknya. Rendahnya kemampuan komunikasi matematis juga didukung oleh penelitian Ansari (Widyastuti. 2015, p. 4) yang menyatakan bahwa siswa Sekolah Menengah Atas di Provinsi Aceh Darussalam rata-rata kurang terampil dalam berkomunikasi untuk menyampaikan informasi seperti menyampaikan ide dan mengajukan petanyaan serta menanggapi petanyaan atau pendapat orang lain.

Dapat disimpulkan bahwa kemampuan komunikasi matematis siswa sama pentingnya dengan pemahaman matematis. Namun seiring dengan rendahnya pemahaman matematis turut membuat kemampuan komunikasi matematis siswa rendah.

\section{KESIMUPLAN}

Berdasarkan hasil penelitian dan pemahasan maka dapat ditarik kesimpulan terdapat hubungan positif dan signifikan antara kemampuan komunikasi dan pemahaman matematis siswa kelas $X$ IPA SMA Negeri 7 Balikpapan Tahun Ajaran 2017/2018

\section{DAFTAR PUSTAKA}

Alamsyah, N. (2015). Pengembangan Instrumen Komunikasi Matematika Untuk Siswa SMP. Research and Development
Journal Of Education, Vol 2 Nomor 1 hal 29-40.

Amelia, F., \& Trismawati, M. (2015). Hubungan Antara Kemampuan Komunikasi Lisan dan Kemampuan Pemahaman Matematis Terhadap Hasil Belajar Matematika Siswa Kelas VIII SMP Negeri 4 Batam Tahun Pelajaran 2013/2014. Jurnal Program Studi Pendidikan Matematika, Vol 4 Nomor 2 hal 10-20.

Ariani, D. N. (2017). Strategi Peningkatan Kemampuan Komunikasi Matematis Siswa SD/MI. Jurnal Madrasah Ibtidaiyah, Vol 3 Nomor 1 hal 96107.

Asnawati, S. (2013). Peningkatan Kemampuan Komunikasi Matematis Siswa SMP dengan Pembelajaran Kooperatif Tipe Teams - Games - Tournaments. Jurnal Euclid ISSN : 2355-1712, Vol 3 Nomor 2 hal 561-567.

Fatqurhohman. (2015). Pemahaman Konsep Matematika Siswa Dalam Menyelesaikan Masalah Bangun Datar. Jurnal Ilmiah Pendidikan Matematika, Vol 4 Nomor 2 hal 127-133.

Hodiyanto. (2017). Kemampuan

Komunikasi Matematis Dalam

Pembelajaran Matematika. AdMathEdu, Vol 17 Nomor 1 hal 9-18.

Khoiriyah, N., Sujadi, I., \& Subanti, S. (2016). Kemampuan Komunikasi Matematis Siswa Kelas VII SMP Negeri 1 Mojolaban Tahun Pelajaran 2014/2015. Journal of Mathematics and Mathematics Education, Vol 6 Nomor 1 hal 3446. 
Maarif, S., \& Nurmila, R. (2015). Komunikasi Matematika Tertulis Dalam Menyelesaikan Masalah Matematika. Jurnal Apotema, Vol 1 Nomor 1 hal 28-36.

Martunis, Ikhsan, M., \& Rizal, S. (2014). Meningkatkan Kemampuan Pemahaman dan Komunikasi Matematis Siswa Sekolah Menengah Atas Melalui Pembelajaran Generartif. Jurnal Didaktik Matematika, Vol 1 Nomor 2 hal 75-84.

Misel, \& Suwangsih, E. (2016). Penerapan Pendekatan Matematika Realistik Untuk Meningkatkan Kemampuan Representasi Matematis Siswa. Metodi Didaktik, Vol 10 Nomor 2 hal 27-36.

Nufus, H., \& Ariawan , R. (2017). Keterkaitan Hubungan Antara Kemampuan Komunikasi dan Penalaran Matematis Siswa. Jornal of Reseacrh in Mathematics Learning and Education, Vol 2 Nomor 1 hal 2942.

Oktavia, F. (2016). Upaya Komunikasi Interpersonal Kepala Desa Dalam Memediasi Kepentingan PT. Bukit Borneo Sejahtera Dengan Masyarakat Desa Long Lunuk. eJurnal Ilmu Komunikasi, Vol 4 Nomor 1 hal 239-253.

Putra, H. D., Setiawan, H., Nurdianti, D., Retta, I., \& Desi, A. (2018). Kemampuan Pemahaman Matematis Siswa SMP di Bandung Barat. JPPM, Vol 11 Nomor 1 hal 19-30.

Ramellan, P., Musdi, E., \& Armiati. (2012). Kemampuan Komunikasi Matematis dan Pembelajaran Interaktif. Jurnal Pendidikan Matematika Part 2, Vol 1 Nomor 1 hal 77-82.
Sari, D. P., Nurochmah, N., Haryadi, H., \& Syaiturjim, S. (2016). Meningkatkan Kemampuan Pemahaman Matematis Melalui Pendekatan Pembelajaran Student Teams Achivement Division. Jurnal Riset Pendidikan Matematika, Vol 3 Nomor 1 hal 16-22.

Sela, Halini \& Yani, A. (2017). Hubungan Kemampuan Penalaran Induktif dengan Pemahaman Konsep pada Materi Operasi Hitung Pecahan di SMP. Jurnal Pendidikan Matematika, Vol 2 Nomor 2, hal 1- 19.

Sugiyono. (2015). Metode Penelitian Pendidikan. Bandung: Alfabeta.

Syahbana. (2013). Peningkatan Kemampuan Pemahaman Matematis Mahasiswa Melalui Strategi Metakognitif. Edumatica, Vol 3 Nomor 2 hal 1-12.

Widyastuti, E. (2015). Peningkatan Kemampuan Pemahaman Konsep dan Komunikasi Matematis Siswa dengan Menggunakan Pembelajaran Kooperatif Tipe Jigsaw . Jurnal Pendidikan Matematika, Vol 1 Nomor 1, hal 1-14.

Wijaya, H. P., Sujadi, I., \& Riyadi. (2016). Kemampuan Komunikasi Matematis Siswa Sesuai Dengan Gender Dalam Pemecahan Masalah Pada Materi Balok Dan Kubus (Studi Kasus Pada Siswa SMP Kelas VIII SMP Al-Azhar 29 Semarang. Jurnal Elektronik Pembelajaran Matematika, Vol 4 Nomor 9 hal 778-788. 